\title{
Correction to: The French welfare state revisited: the puzzling politics of mental health policy
}

\author{
Isabel M. Perera ${ }^{1}$
}

Published online: 20 November 2020

(c) Springer Nature Limited 2020

\section{Correction to: French Politics https://doi.org/10.1057/s41253-020-00133-7}

The first sentence of the fourth paragraph under section "Contre la médecine libérale" was published incorrectly. The correct sentence should read as follows:

Since the nineteenth century, French psychiatry has been tied to the state.

Publisher's Note Springer Nature remains neutral with regard to jurisdictional claims in published maps and institutional affiliations.

The original article can be found online at https://doi.org/10.1057/s41253-020-00133-7.

\section{Isabel M. Perera}

isabel.m.perera@cornell.edu

1 Department of Government, Cornell University, White Hall, Ithaca, NY 14850, USA 